\title{
Independence: The Fall Of Andersen And The Rise Of Sarbanes Oxley
}

H. Francis Bush, (E-mail: bushhf@vmi.edu), Virginia Military Institute

\begin{abstract}
In this study, the author examines the audit firms' fees associated with audit services and auditrelated services as a percentage of total fees charged to individual firms as reported to the SEC. This study was motivated by discussion of the impacts on audit opinions of the amount of work beyond an audit for which an auditing firm contracts. The results indicate that the fees that Arthur Andersen charged its individual clients indeed had a lower percentage of total fees associated with audit work. Further, for the year 2002, on average, firms reported a higher percentage of fees from auditors were associated with audit work. Firms that previously contracted with Arthur Andersen contracted significantly less non-audit services than their counterparts.
\end{abstract}

\section{INTRODUCTION}

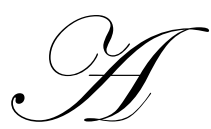

s 2001 came to an end, one of the Big Five accounting firms, Arthur Andersen was implicated in the collapse of Enron. The actions of the principals of Arthur Andersen ultimately led to indictments and the conviction of a felony for Andersen. As these proceedings were making their way through the courts and the media, various events began to unfold - Corporations began to dismiss Andersen as their auditor, and the Sarbanes-Oxley Act of 2002 was introduced and passed in the Congress of the United States. Among the various issues that this act examined was auditors' independence. Specifically, could services performed by auditing firms outside of the scope of the audit impair auditors' independence?

Concerns had circulated that perhaps the proportion of revenues that Andersen had generated from performing non-audited related services for Enron had affected their opinion. In response, the Sarbanes-Oxley Act of 2002, specifically, amended the requirements related to auditor independence as required by the Securities and Exchange Act of 1934. Section 201 focused on services provided by auditors that are outside of the scope of the audit. Further, the Sarbanes-Oxley Act of 2002 declares, "(9) any other service that the Board determines, by regulation, is impermissible." (H.R. 3763, Sec. 201: a).

This study reviews the audit fees of Fortune 500 firms for the years 2001 and 2002. The results provide evidence that Andersen did indeed have a greater percentage of fees in non-audit activities than other firms. Although the existence of a higher proportion of revenues does not prove a lack of independence, it does indicate that Andersen had a different fee structure that could have affected the auditors' motivation.

The remainder of this paper is organized as follows. In Section 2, I summarize the arguments and present the hypotheses. I present the data and methodology in Section 3. In Section 4, I discuss the empirical results, and in Section 5, I summarize the conclusions, implications, and limitations of this study.

\section{DEVELOPMENT OF THE HYPOTHESES}

The collapse of Enron brought much attention to the accounting profession as another high-profile audit failure. As a result of this failure, many changes have taken place. On March 7, 2002, Andersen was indicted for 
obstruction of justice. Obstruction of justice is a felony, which increased the risk for Andersen from severe financial liabilities to ultimately its very existence. The doors of Andersen were closed. Congress passed the Sarbanes-Oxley Act of 2002 providing: (1) the establishment of the Public Company Accounting Oversight Board, (2) stronger guidelines for auditor independence, (3) increased responsibilities for corporate officers, (4) enhanced financial disclosures, and (5) related penalties.

A persistent question surrounding any audit failure focuses on the independence of the auditor. Various conflicts have been studied relating to auditor independence. For example, the Sarbanes-Oxley Act specifically reviews mandatory audit rotation, which has been studied by various authors. (See Meyers et. al., 2003, Johnson and Lys, 1990.) However, other authors have looked at the impact of non-audit services on auditor independence, in particular management advisory services (MAS). (See Dopuch and King, 1992 and Pany and Reckers, 1988.) The focus of this study lies in the latter issue.

Pany and Reckers (1988) investigated the perception of auditor independence among loan officers and financial analysts. Loan officers reviewed a loan application while financial analysts considered a possible common stock investment, each with one of four different levels of performance of MAS - 0\%, 25\%, 60\%, and 90\%. They concluded "that auditor provided MAS exerts little, if any, effect on typical investment or credit granting decisions, on perceptions of financial statement reliability, or on perception of auditor independence" (p. 38).

Dopuch and King (1992) applied an experimental markets study on the effects of providing both auditing and MAS. They chose this approach because of the complex interactions created by offering both auditing and MAS. They noted that production economies and legal constraints are difficult "to incorporate into multiperiod, multiagent models of MAS and auditing" (p. 61). They found that although the frequency of MAS contracts were not significantly different when firms were restricted to offering one or the other service, the fees were higher when a firm could only offer one service. This finding would be consistent with production economies. Dopuch and King concluded that allowing one firm to provide both services did not significantly improve the overall relative market efficiencies.

The conviction and subsequent demise of Andersen provides an alternative approach. The proportion of fees associated with auditing activity as opposed to other activity is investigated to determine if there is any evidence that Andersen had a different fee structure and underlying combination of provided services. However, the relatively sudden demise of Andersen provides an opportunity to look at existing conditions that might have caused the errors in judgment related to the Enron audit. Although existence is not the same as causality, the lack of existence would disprove causality.

If providing non-audit services were a hindrance to auditor independence, then for Andersen to have been compromised it is necessary to demonstrate that they had a lesser percentage of audit service fees than did those of the firm that replaced them. If Arthur Andersen did not have a significantly small proportion of its clients' fees in audit services, the independence argument is more difficult to make. Although the issue is independence, the SEC reporting requirements under the Sarbanes-Oxley Act 2002 have increased the information about reporting auditors' fees, the focus is strictly on audit fees and audit-related fees. Thus, the first pair of alternative hypotheses is formulated as follows:

$\mathbf{H}_{\mathbf{a}}$ : The mean proportion of Andersen's total fees for audit services was less than the mean proportion of the total fees of the firm that replaced Andersen.

$\mathbf{H}_{\mathbf{a}} \quad$ The mean proportion of Andersen's total fees for audit and audit-related services was less than the mean proportion of the total fees of the firm that replaced Andersen.

A comparison of auditor fees before and after the collapse of Enron is clearly compounded by this event. Consequently, any differences between Andersen's fee structure and other accounting firms must be investigated. The second pair of alternative hypotheses is: 
$\mathbf{H}_{\mathbf{a}}$ : The mean proportion of Andersen's total fees for audit services was less than the mean proportion of other firms' total fees in 2001.

$\mathbf{H}_{\mathbf{a}}$ : The mean proportion of Andersen's total fees for audit and audit-related services was less than the mean proportion of other firms' total fees in 2001.

Further, the discussion preceding the passage of the Sarbanes-Oxley Act of 2002 renewed concern about the conflict between auditors' independence and providing non-audit services. The impact of this concern would be reflected in auditing firms to decrease their efforts in providing non-audit related services along with audit services. The alternative hypotheses are as follows:

$\mathbf{H}_{\mathbf{a}}$ : The mean proportion of other accounting firms' total fees for audit services in 2001 was less than the mean proportion of other firms' total fees in the following year.

$\mathbf{H}_{\mathbf{a}}$ : The mean proportion of other accountings' total fees for audit and audit-related services in 2001 was less than the mean proportion of other firms' total fees in the following year.

Lastly, firms that were previously associated with Arthur Andersen might choose to take a proactive approach to independence. If their management were concerned about contracting for non-audit services, they would now have a higher proportion of their audits fees associated with auditing services. The final alternative hypotheses are as follows:

$\mathbf{H}_{\mathbf{a}}$ : The mean proportion of accounting firms' total fees for audit services for firms previously contracting with Arthur Andersen was higher than the mean proportion of other firms' total fees in the following year.

$\mathbf{H}_{\mathbf{a}}$ : The mean proportion of accountings' total fees for audit and audit-related services for firms previously contracting with Arthur Andersen was higher than the mean proportion of other firms' total fees in the following year.

\section{DATA AND METHODOLOGY}

A widely accepted classification of large firms in the U.S. is based on Fortune Magazine. Consequently, firms for this study were selected from the Fortune 500. Initially, it was hoped that all firms would be included. However, several firms were excluded because they were involved in mergers, bankruptcy, or data was not available in the SEC's Edgar database. The existence of a merger or bankruptcy could impact the nature of the fees. The resulting sample was composed of 86 firms that had contracted with Andersen for the years 2000 and 2001, and 352 firms that had not contracted with Andersen for those years. At the time of the study, one firm that contracted with Andersen and five firms that had not contracted with Andersen did not have their proxy statements available on Edgar.

Using the firms listed by Namelst.com as the Fortune 500, data was collected identifying each firm's auditor for the years 2000, 2001, and 2002 and the auditors' fees for 2001 and 2002. The data was collected from the firms' websites, and from the Annual Report (10-K) and Other Definitive Proxy Statement (DEF 14A) available on Edgar.

Each firm was segregated between those that had contracted with Andersen during the years 2000 and 2001 and those that had contracted with other auditing firms. For each firm and each year the fees were categorized between those for audit services, audit-related services, and other fees. Fees that were reported for other identified services, such as tax and system design, were included as other fees because the focus is the proportion of fees related to auditing versus other services. Further, not all firms provided such details. Two variables were calculated for each firm: the proportion of the total fees for audit service, AF- $\%$ i, and the proportion of total fees for audit and auditrelated services, TAF- $\%$ i. The calculations were as follows:

$\mathrm{AF}-\%_{\mathrm{i}}=$ Audit Fees $/$ (Audit Fees + Audit-Related Fees + Other Fees)

$\mathrm{TAF}_{-} \%_{\mathrm{i}}=($ Audit Fees + Audit-related Fees $) /($ Audit Fees + Audit-Related Fees + Other Fees $)$ 


\section{EMPIRICAL RESULTS}

Table 1 presents the descriptive statistics for all the firms' audit fees. First, for the firms that had contracted with Andersen, the mean proportion of fees for audit services and the sample variances are provided for the year with Andersen and the subsequent year. Second, for firms that had contracted with other firms, the same descriptive statistics are provided for the year 2001 and 2002.

\begin{tabular}{|l|c|c|}
\hline \multicolumn{2}{|c|}{ Firms Originally Contracting with Arthur Andersen } \\
\hline \multicolumn{2}{|c|}{ After Andersen } \\
\hline Number of Firms & With Andersen & $85 *$ \\
\hline Mean Proportion of Fees for Audit Services & 86 & .6463 \\
\hline Variance of the Proportion of Fees for Audit Services & .3610 & .0323 \\
\hline Mean Proportion of Fees for Audit and Audit-Related Services & .0359 & .7386 \\
\hline Variance of the Proportion of Fees for Audit and Audit-Related Services & .4814 & .0336 \\
\hline \multicolumn{2}{|c|}{ Firms Not Contracting with Arthur Andersen in 2000 and 2001 } \\
\hline \multicolumn{2}{|c|}{20486} \\
\hline Number of Firms \\
\hline Mean Proportion of Fees for Audit Services & 352 & 2002 \\
\hline Variance of the Proportion of Fees for Audit Services & .4047 & $347 *$ \\
\hline Mean Proportion of Fees for Audit and Audit Related Services & .0344 & .4987 \\
\hline Variance of the Proportion of Fees for Audit and Audit Related Services & .5530 & .0327 \\
\hline
\end{tabular}

*Not all companies had filed a proxy with the SEC when the database was established.

A test of two means from independent samples revealed the following concerning the hypotheses about Andersen's fee structure. First, the mean proportion of fees for Andersen clients was compared to the mean proportion for these firms the following year when another firm was selected. (In all cases the new firm was one of the remaining Big Four CPA firms.) For audit services only, the Z-score was 10.10; for audit services combined with audit-related services, the Z-score was 8.30. In both cases, the null hypotheses that the mean proportion of fees of Andersen was no less than the mean proportion of fees of the firm replacing Andersen was rejected at $\alpha=.001$. This evidence is consistent with the notion that Andersen generated significantly more revenues from non-audit related services. ${ }^{1}$

The sequential timing of the two measures, however, may have impacted the significance of the previous tests. The collapse of Enron and Andersen could have changed the market for services from auditing firms. Further, the discussion preceding the passage of Sarbanes-Oxley Act of 2002 may have impacted contracting decisions by either corporate management or auditing firms. The mean proportion of fees for Andersen clients was compared to the mean proportion for firms who contracted audit services from another firm in the same year, 2001. For audit services only, the Z-score was 1.92 which rejects the null hypothesis that Andersen's mean proportion of fees associated with audit series is no less than that of other accounting firms at $\alpha=.05$. For audit services combined with audit-related services, the Z-score was 2.69, which rejects the null hypothesis that Andersen's mean proportion of fees associated with the combination of audit and audit-related services is no less than other accounting firms at $\alpha=.01$. Although these results are not as significant as the first results, these results still provide evidence that Andersen generated significantly more revenues from non-audit related services.

The decline in statistical significance when the effects of sequential data are removed drives the last pair of hypotheses concerning the fee structure of the other accounting firms before and after the collapse of Enron and Andersen. The mean proportion of audit fees for clients of other accounting firms was compared to the mean proportion of audit fees for these firms the following year. (Firms that had switched auditors were not included.) For audit services only, the Z-score was 6.78; for audit services combined with audit-related services, the Z-score was 5.46. In both cases, the null hypotheses that the mean proportion of audit fees of the other firms were no less than the

\footnotetext{
${ }^{1}$ Similar results were obtained when a match-pair design was applied to the 85 firms for which data was available
} 
mean proportion in the following years was rejected at $\alpha=.001$. This evidence is consistent with the notion that contractual relations between a firm, and the types and amounts of work contracted with accounting firms had changed. $^{2}$

Finally, the reaction of firms that had contracted previously with Arthur Andersen was examined. These firms were hypothesized to spend a greater proportion of their audit fees on audit and audit related services only. For audit services only and for audit services combined with audit-related services, the Z-scores were 6.78 and 4.40. At $\alpha$ $=.001$, there is also sufficient evidence to reject these null hypotheses. Consequently, it appears that management has taken a proactive approach to independence. When contracting audit services.

\section{CONCLUSIONS, IMPLICATIONS, AND LIMITATIONS}

The evidence suggests that there has been differentiation among the revenues generated by the services provided by accounting firms to large firms in the United States. First, the auditing firms that replaced Andersen provided significantly less non-audit related services to Andersen's clients. Second, during the year 2001, Andersen billed significantly more fees for non-audit related services than other accounting firms. Third, other firms provided significantly less non-audit related services in the year following the demise of Andersen. Although these results do not demonstrate the causality of excessive non-audit related activity and impaired independence (or audit failure), they do provide evidence of the coexistence of these factors.

Given these results, further study should be made to accomplish various aspects of this study. Replications could expand the applicability of these findings to smaller firms, and to years before and after the scope of this study. Such replications would provide greater understanding of the impact of Sarbanes-Oxley Act of 2002 and the collapse of Enron and Andersen. Further, a significant portion of Sarbanes-Oxley Act of 2002 is based on the belief that excessive contracting of non-audit related services impairs auditors' independence. The coexistence demonstrated in this study needs to be elevated to the level of causality to justify such action.

The application of these results is limited by the nature of the sample and use of time-series data. Even though the sample was composed of more than 85 percent of the firms from the Fortune 500, the results are not necessarily relevant for smaller firms. Further, focusing on the years surrounding the collapse of Enron and Andersen may capture other variables for which controls were not applied. As mentioned above, these limitations can be addressed in additional studies.

\section{REFERENCES}

1. $\quad 107^{\text {th }}$ US Congress. 2002. Sarbanes-Oxley Act of 2002, H.R. 3763. 116 Stat. 745.

2. Myers, J. N., Myers, L. A., and Omer, T. C. 2003. Exploring the term of the auditor-client relationship and the quality of earnings: A case for mandatory auditor rotation?. The Accounting Review. 78 (July): 779-799.

3. Johnson, W. B., and Lys, T. 1990. The market for audit services: Evidence from voluntary auditor changes. Journal of Accounting and Economics 12 (January): 281-308.

4. Pany, K. and Reckers, P. M. J. 1988. Auditor performance of MAS: A study of its effects on decisions and perceptions. Accounting Horizons 2 (June): 31-38.

5. Dopuch, N. and King, R. R. 1992. The impact of MAS on Auditors' Independence: An experimental market study. Journal of Accounting Research. 29 (supplement): 60-98.

\footnotetext{
${ }^{2}$ Similar results were obtained when a matched pair design was applied to the 347 firms for which data was available for both years.
} 


\section{NOTES}

